College of Veterinary Medicine and Animal Production,

Sudan University of Science and Technology.

\title{
THE EFFECT OF FEEDING COWPEA \\ (Vigna ungialata) ON BROILER CHICKS \\ PERFORMANCE AND SOME \\ CARCASS QUALITY MEASUREMENTS
}

(With 4 Tables)

By

B.H. ELJACK; I.M.T. FADLALLA and M.T. IBRAHIM

(Received at 12/10/2009)

\section{SUMMARY}

The present study was conducted to investigate the effect of feeding graded levels (zero, 10, 20 and 30\%) of cowpea on broiler chick's performance, dressing percentage and carcass cuts relative weight. A total of 160 unsexed broiler chicks (Hubbard) were randomly distributed into four dietary treatments and each treatment contained four replicates (10 birds/replicate). Feeding graded levels of cowpea resulted in no significant differences in total and weekly feed intake (g/bird), but it tended to be higher for birds fed the control diet (zero level). Total and weekly weight gain ( $\mathrm{g} / \mathrm{bird})$ and feed conversion ratio of six weeks old broiler chicks were significantly $(\mathrm{P}<0.05)$ improved for birds fed all levels of coepea compared to the control diet. Dressing percentage was significantly $(\mathrm{P}<0.05)$ improved by inclusion of cowpea, while carcass cuts relative weights showed a significant $(\mathrm{P}<0.05)$ improvement in the relative weight of breast and thigh of carcasses of birds kept on $30 \%$ cowpea compared to the other dietary treatments.

Key Words: Cowpea, body weight gain, feed conversion ratio, dressing percentage, carcass cuts.

\section{INTRODUCTION}

The development of the growing poultry industry in the Sudan is dependent on the utilization of local feed ingredients and industrial by-products. Cowpea (Vigna ungialata) is a leguminous summer crop, which is one of the most important protein sources in the diets of animals and poultry in tropical Africa, particularly in the Sahel regions. 
It is a highly nutritious crop with a dry seed protein content of $25 \%$ which is highly digestible compared to other legumes (Silano et al., 1981; Olaghobo and Fetuga 1983).

The chemical composition of cowpea green fodder and seeds showed broad variations. Sharma and Singhania (1992) found that, dry matter content of cowpea was 82\%, while Fawzi and Abdelrahim (1968) and Silanino et al. (1981) reported that dry seed protein content of cowpea was about $25 \%$; ether extract $2.4 \%$; crude fiber $28.9 \%$; nitrogen free extract 43.1 and protein digestibility was higher than that of other legumes. Similar results were reported by Olaghobo and Fetuga (1983). However, great variability in cowpea chemical composition according to the cultivar of cowpea mentioned by Marconi et al. (1990), who reported that protein content ranged between 23.4 to $28.2 \%$, and protein digestibility with an average value of $77.9 \%$. High protein quality of cowpea flour was reported by Dario and Salgado (1994) and Enwere et al., 1998)

In a study conducted to determine the possible level of production with local feeds of low nutritive value, using no animal protein, Wethli and Paris (1979) reported that the control birds has significantly heavier weight than those fed other dietary treatment. For different cowpea varieties, there were no significant differences in either final body weight or weight gain among treatments for local cowpea varieties. The body weight and gain for birds fed the treated diets were lower than the control by about $15 \%$ and $28 \%$ respectively.

The present experiment was designed to investigate the effect of feeding graded levels (Zero, 10, 20 and 30\%) of cowpea cultivated in Sudan on broiler chick performance, dressing percentage and carcass cuts relative weights.

\section{MATERIALS and METHODS}

The experiment was conducted during the period between June - July 2004, in which the ambient temperature ranged from 34 to $42 \mathrm{C}^{\circ}$. The experiment was carried out in an open sided deep litter poultry house with a concerted floor, corrugated iron-sheets roof.

A total of two hundred, one-day-old unsexed broiler chicks (Hubbard) were fed the control diet for two days as an adaptation period. At the end of day two, chicks were assigned into 16 pens in groups of 10 chicks for each. Four diets were formulated to meet the nutrient requirements of broiler chicks as outlined by NRC (1994). Cowpea was added to the diet at the rate of zero, 10, 20 and 30\%. Zero level serves 
as a control diet. Table (1) shows the chemical composition of cowpea. Experimental diet composition and calculated analysis are shown in Table (2). Weekly Feed intake, weight gain and feed conversion ratio were recorded for the individual replicate (pen) of each dietary treatment. Feed and water were provided ad libitum.

At the end of the six weeks, the birds (one male and one female) were selected on the basis of average bird pen weight. They were individually weighed, tagged, slaughtered, scalded manually, plucked and allowed to drain. Eviscerated fed carcasse weight and dressing percentage were determined. From the 32 eviscerated carcasses, 16 carcasses were selected (4 carcasses/ dietary treatment), they were individually weighed and divided into three cuts. Breast, thigh and drum stick were weighed individually and their relative weights were recorded.

The proximate analysis of cowpea was carried out according to Association of Official Analytical Chemists (A 0 A C, 1980).

\section{Statistical Analysis:}

A completely randomized design was used in the experiment. The collected data of the experiment were subjected to analysis of variance and the least significant difference test was used to assess the significant among treatment means as described by Gomez and Gomez (1984).

Table 1: Chemical Composition of Cowpea:

\begin{tabular}{|l|c|}
\hline \multicolumn{1}{|c|}{ Component } & $\%$ \\
\hline Dry matter & 93.3 \\
\hline Crude protein & 20.91 \\
\hline Ether extract & 2 \\
\hline Crude fiber & 3.4 \\
\hline Ash & 4.1 \\
\hline Nitrogen free extract ${ }^{(1)}$ & 62.89 \\
\hline Metabolizable energy $(\mathrm{ME})(\mathrm{MJ} / \mathrm{kg})^{(2)}$ & 13.4 \\
\hline
\end{tabular}

(1) N.F.E. was calculated by difference

(2) M.E. was calculated value according to the equation of Lodhi, et al. (1976). 
Table 2: Ingredients and nutrients composition of the experimental diets

\begin{tabular}{|l|c|c|c|c|}
\hline \multirow{2}{*}{ Ingredients } & \multicolumn{4}{c|}{ Treatments } \\
& 0.00 & 10.00 & 20.00 & 30.00 \\
\hline Sorghum & 63.6 & 56.6 & 49.6 & 42.6 \\
\hline GNC & 28 & 25 & 22 & 19 \\
\hline Cowpea & 0.0 & 10 & 20 & 30 \\
\hline Concentrates & 5 & 5 & 5 & 5 \\
\hline Dicalcium phosphate & 1.25 & 1.25 & 1.25 & 1.25 \\
\hline Limestone & 1.3 & 1.3 & 1.3 & 1.3 \\
\hline Lysine & 0.34 & 0.34 & 0.34 & 0.34 \\
\hline Methionine & 0.11 & 0.11 & 0.11 & 0.11 \\
\hline Common salt & 0.3 & 0.3 & 0.3 & 0.3 \\
\hline Multivitamin premix & 0.1 & 0.1 & 0.1 & 0.1 \\
\hline Nutrient level & & & & \\
\hline ME mJ/kg & 13 & 13 & 13 & 13 \\
\hline CP \% & 23.1 & 23 & 22.9 & 22.9 \\
\hline Lysine \% & 1.2 & 1.2 & 1.2 & 1.2 \\
\hline Methionine \% & 0.5 & 0.5 & 0.5 & 0.49 \\
\hline Calcium \% & 1.1 & 1.1 & 1.1 & 1.1 \\
\hline Av. phosphorus & 0.48 & 0.48 & 0.48 & 0.48 \\
\hline
\end{tabular}

*Superconcentrate provide per $\mathrm{kg}$ : $10.04 \mathrm{Mj} / \mathrm{kg}(\mathrm{ME}), 40 \% \mathrm{CP}$, $6 \%$ Lysine, $3.5 \%$ methionine, $5 \%$ calcium, $5 \%$ fat, $5 \% \mathrm{CF}$ and $2.3 \%$ sodium

\section{RESULTS}

Table 3: Effect of feeding cowpea on the performance of six weeks old broiler chicks.

\begin{tabular}{|c|c|c|c|c|c|}
\hline \multirow{2}{*}{ Parameter } & \multicolumn{4}{|c|}{ Cowpea inclusion rate } & \multirow[b]{2}{*}{ SEM } \\
\hline & Control & $0.0 \%$ & $10 \%$ & $20 \%$ & \\
\hline Mean total wt. gain (g) & $1683.29^{\mathrm{C}}$ & $1830.05^{\mathrm{b}}$ & $1808.26^{b}$ & $2152.02^{\mathrm{a}}$ & 26.8 \\
\hline Final live body wt. (g) & $1731.25^{\mathrm{C}}$ & $1877.75^{\mathrm{b}}$ & $1856.25^{b}$ & $2200^{a}$ & 49.1 \\
\hline Mean total feed intake (g) & 3660 & 3144 & 3422 & 3450 & 72.2 \\
\hline $\begin{array}{l}\text { Feed conversion ratio } \\
\text { (g feed/g gain) }\end{array}$ & $2.2 \mathrm{c}$ & $1.7^{\mathrm{b}}$ & $1.9^{\mathrm{b}}$ & $1.6^{\mathrm{a}}$ & 13.4 \\
\hline
\end{tabular}

Values are means of 40 birds/ treatment

Values within a row with different superscript are significantly different $(\mathrm{P}<0.05)$ 
Table 4: Effect of feeding cowpea on dressing percentage and carcass cuts relative weight of six-week-old broiler chicks.

\begin{tabular}{|c|c|c|c|c|c|c|}
\hline \multirow{2}{*}{$\begin{array}{c}\text { Treatment } \\
\text { Parameter }(\%)\end{array}$} & \multicolumn{4}{|c|}{ Cowpea inclusion rate $(\%)$} & \multirow{2}{*}{ SEM } & \multirow{2}{*}{$\begin{array}{c}\text { Level of } \\
\text { significanc }\end{array}$} \\
\hline & Control & $10 \%$ & $20 \%$ & $30 \%$ & & \\
\hline $\begin{array}{c}\text { Dressing } \\
\text { percentage }\end{array}$ & $68^{\mathrm{b}}$ & $72.0^{\mathrm{c}}$ & $72.7^{b}$ & $76.0^{\mathrm{a}}$ & 2.5 & $*$ \\
\hline Breast Rw. & $29^{\mathrm{b}}$ & $27^{\mathrm{b}}$ & $26^{\mathrm{b}}$ & $34^{\mathrm{a}}$ & 6.6 & NS \\
\hline Thigh Rw. & $15.8^{\mathrm{b}}$ & $16.2^{\mathrm{b}}$ & $21.7^{\mathrm{b}}$ & $26.7^{\mathrm{a}}$ & 8.8 & NS \\
\hline Drum stick & 12.6 & 13.2 & 13.3 & 13.6 & 2.2 & NS \\
\hline
\end{tabular}

- Values are means of 4 birds/treatment (ressing \%)

- Values within a row with different superscript are significantly different (carcass cuts relative weight).

- Significant at $(\mathrm{P}<0.05)$

NS: not statistically significantly.

\section{DISCUSSION}

The results of feeding graded levels of cowpea $(0,10,20$, and $30 \%$ ) on the performance of broiler chicks are presented in Table (3). The results showed that there were no significant differences in the total feed intake (g), but it tended to be higher for birds fed the control diet. The total weight gain $(\mathrm{g})$, final body weight gain $(\mathrm{g})$ and feed conversion ratio ( $\mathrm{g}$ feed/g gain) were significantly $(\mathrm{P}<0.05)$ affected by the inclusion of cowpea. It can be seen that all parameters were significantly $(\mathrm{P}<0.05)$ improved by feeding of cowpea, so that the best results were obtained by birds fed 30\% cowpea followed by those fed the other tested diets.

The significant improvement in live weight gain and feed conversion ratio for birds' fed-cowpea might be due to the high protein digestibility of cowpea which led to improve the efficiency of nutrient utilization.

The protein digestibility of cowpea was found to be higher than the other legumes (Ologhobo and Fetuga 1983; Silanino et al. 1981).

In addition, the acceptable essential amino acids profile of cultivated cowpea which reported by Elias (1963); Khan et al. (1978) and Carnvale (1990) may explain the significant improvement in live weight gain and feed conversion ratio of birds fed graded levels of cowpea. It can be seen that the cultivated cowpea is a good source for 
minerals, mainly iron $8 \mathrm{mg} / 100 \mathrm{~g}$ and zinc $5 \mathrm{mg} / 100 \mathrm{~g}$ (Carnvale, 1990) might played a vital role in the improvement of the total weight gain and feed conversion ratio for birds fed cultivated cowpea compared to those fed the control diet in the present experiment.

However, no available reports in the use of cowpea in poultry nutrition. The findings of the present study were disagreed with the results reported by Wethli and Paris in Mozambique (1979) and might be due to the variation of cowpea chemical composition and its nutritive value.

Although the total feed intake was not significantly differentamong dietary treatments, feed intake tended to be lower for birds fed different levels of cowpea. This decrease in the feed intake might be related to the palatability of cow pea based diets. However, the palatability and digestibility of cowpea was found to be lower in comparison with that of lubia (Tarawali et al., 1991)

The dressing percentage was significantly $(\mathrm{P}<0.05)$ improved by inclusion of cowpea. The birds kept on $30 \%$ cowpea showed the best dressing percentage followed by those kept on other levels as shown in Table (4).

The carcass cuts relative weights showed a significant $(\mathrm{P}<0.05)$ improvement in breast and thigh relative weight for birds kept on $30 \%$ cowpea compared to other dietary treatments, but it tended to increase by the inclusion of cowpea as shown in Table (4).

The improvement in dressing percentage and carcass cuts relative weight for birds fed, cowpea could be explained by the significant improvement in live body weight, because they followed the trend of body live weight.

\section{CONCLUSIONS and RECOMMENDATIONS}

Based on the nature and results of the present study, the following conclusions and recommendations can be drowning:

1. The nutritive value of cultivated cowpea as a non-conventional protein source for poultry is satisfactory and has a positive effects on broiler chicks' performance.

2. The use of cowpea in broiler chicks' diets is resulted in minimizing the feeding cost.

3. The increase and development of cultivation of cowpea can play an important role in the industry of poultry feed in the Sudan. 


\section{REFERENCES}

A.O.A.C. (1980): Official Methods of Analysis. $13^{\text {th }}$ edn. Association of Official Analytical Chemists, Washington, D.C.

Cornovale, E.; Marietta, L.; Marconi, E. and Brosio, E. (1990): Nutritional and hydration properties in cowpea, page $111-118$ in cowpea genetic resources, edited by N.Q. Ng and L.M. Monti. International Institute of Tropical Agriculture (IITA), Ibadan, Nigeria.

Dario, A.C. and Salgado, J.M. (1994): Supplementation of irradiated and non-irradiated cowpea bean (vigna unguiculata L. Walp) protein with cereal proteins. Supplementation of soup with a protein blend of appropriate nutritional value. Plant Foods Hum. Nutr., 46(3): 213-9.

Elias, L.G.; Colindres, $R$. and Bressani, R. (1963): The nutritive value of eight varieties of cowpea (vigna sinensis). J. Food Sci. 29: 118-122.

Enwere, N.J.; McWatters, K.H. and Phillips, R.D. (1998): Effect of processing on some properties of cowpea (vigna unguiculata), seed, protein, starch, flour and akara. Int. J. Food Sci. Nutr., 49(5): 365-73.

Fawzi, H. and A/Rahmim, I. (1967): Economical fattening of kenana calves on Gezira Agricultural by-products. Sudan J. Vet. Sci. and Anim. Husb. 8: 12-123.

Gomez, K.A. and Gomez, A.A. (1984): Statistical Procedure for Agricultural Research. $2^{\text {nd }}$ edn. Wiley and Sons. Inc.

Khan, M.A.; Jacobsen I. and Eggum, B.O. (1978): Nutritive value of some improved varieties of legumes. J. Sci. Food Agri. 30: $395-400$.

Lodhi, G.N.; Singh, D. and Ichponani, V.S. (1976): Variation in nutrient content of feeding stuff rich in protein and reassessments of the chemical method for metabolizable energy estimation for poultry. J. Agric. Sci. Camb., 86: 293 -303.

National Research Council (1994): Nutrient requirements of poultry. 9 edn. National Academy of Sciences Washington.

Ologhobo, A.D. and Fetuga, B.L. (1983): Investigation of the trypsin inhibitor, hemagglutinin, phytic and lannic acid contents of cowpea Vigna unguiculata. Food Chemistry 12: 249 - 254.

Sharma, C.D. and Singhania, D.L. (1992): Performance of cowpea (Vigna unguiculata $\{$ L. $\}$ Walp.) genotypes for fodder trails. Annals of Arid zone 31: 65 - 66. 
Silanino, V.; Bansul, H.C. and Bozzini, A. (1981): Improvement of nutritional quality of food crops. FAO plant production and protection paper N. 34. Food and Agricultural Organization, Rome.

Trawali, S.A. (1991): Preliminary agronomic evaluation of forages legumes for subbumid west Africa. Tropical Agriculture (Trinidad) 68: 88 - 94.

Wethli, E. and Paris, C. (1995): The use of raw materials cultivated in Mozambique in the feeding of growing chickens. Ministry of Agriculture Maputo, Mozambique. 